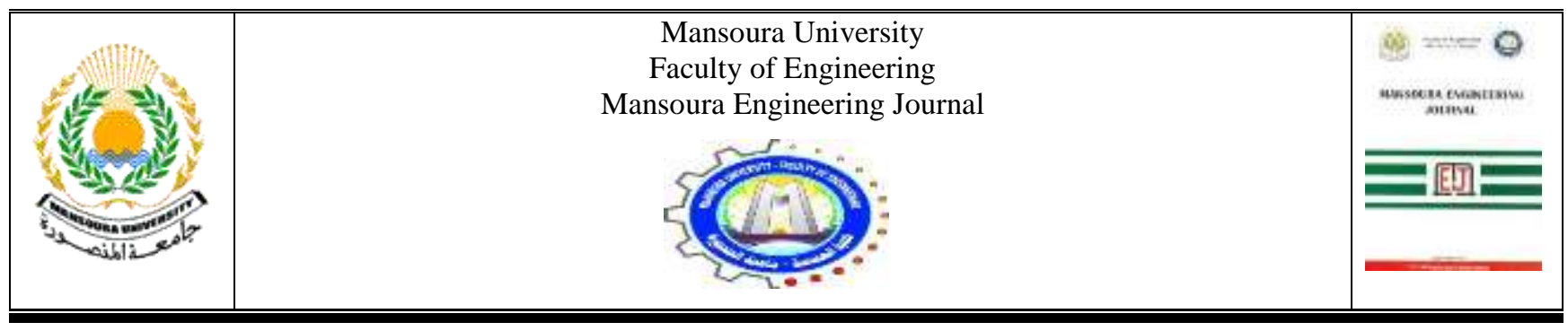

\title{
Sustainable Building Material Technology as an Approach to Thermal Comfort in Low Income Housing in Hot Regions

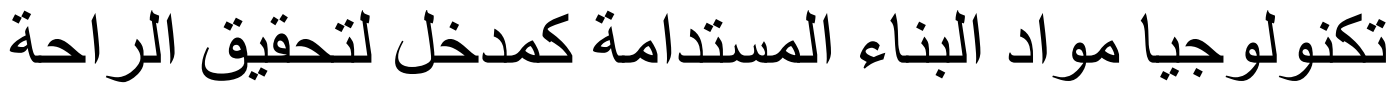

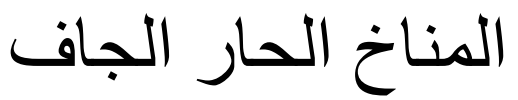

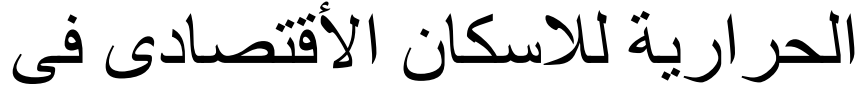

Mohamed Salah, Mona Awad and Yara Kamel

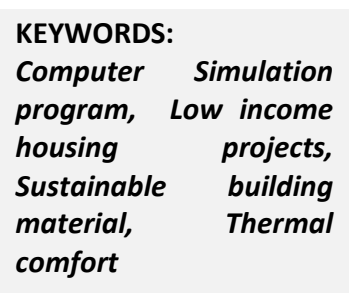

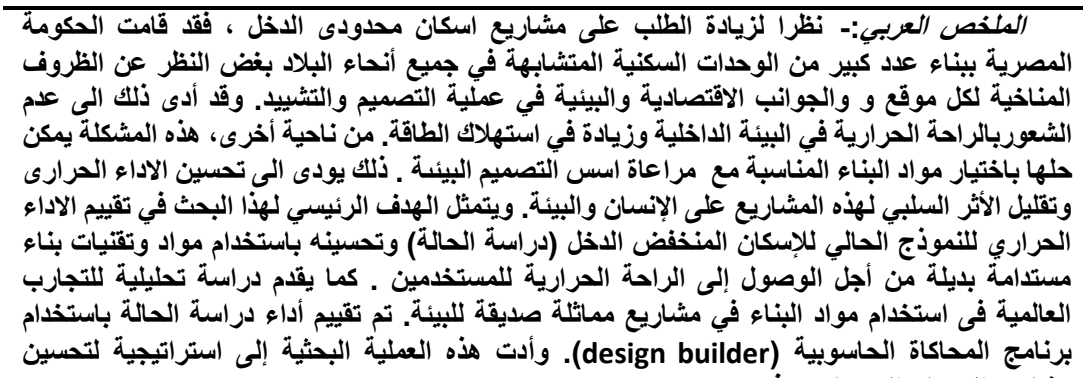

\footnotetext{
Abstract - Due to increasing the demand for low income housing projects, the Egyptian Government has constructed a large number of identical residential units all over the country regardless the climatic condition of each location and the economic and environmental aspects in design and construction process. This has led to lack of thermal comfort in the indoor environment and increasing in energy consumption. On the other hand, this problem can be solved by choosing the appropriate building material with respect to environmental design principles. It can greatly improve the thermal performance and reduce the negative impact of these projects on human and environment. The main aim of this research is to evaluate the thermal behavior of the current low income housing prototype (case study) and improve it using alternative sustainable building materials and techniques in order to reach human thermal comfort. It also provides an analytical study of global experiences on using friendly

Received: 20 February, 2018 - Revised: 22 April, 2018 - Accepted: 24 April, 2018

Mohamed Salah. Professor at Architectural Engineering Department, University of Mansoura, Egypt (e-mail: drsalah22222@hotmail.com).

Mona Awad. Associate professor at Architectural Department, University of Mansoura, Egypt (e-mail: monaawad.74@gmail.com).
}

construction material in an environment friendly similar projects. The performance of the case study evaluated using computer simulation program (design Builder). This research process led to a strategy of improving public housing projects in Egypt.

\section{INTRODUCTION}

$\mathrm{N}$ OWADAYS, researches show that about $60 \%$ of the cost of a low-income housing project is allocated to engineering design and construction materials. Add to that, walls consume $50 \%$ of the total cost of materials and up to $45 \%$ of total construction time. In the last decade, construction technology Witnessed developments in construction material Leading to environmentally appropriate traditional building materials Abandoned and using modern

Yara Kamel. Demonstrator at delta higher institute for engineering and technology, Mansoura, Egypt (e-mail: varakamel@gmail.com). 
western techniques in residential construction, although there are types of projects require the use of eco materials such as low-cost housing in order to achieve human satisfaction and comfort with the minimum cost.

\section{AIM OF THE RESEARCH}

This study aims at approaching the following:

- Discussion, analysis thermal performance of Egyptian low income housing projects.

- Emphasizing the role of the appropriate sustainable building material on improving indoor environment, energy consumption and construction cost in affordable housing unit in hot arid climate of Egypt.

- Examining the use of new building materials for building walls, opening, floor and insulation.

\section{RESEARCH METHODOLOGY}

For achieving the main aim of the research, the study will depend on the following steps. Firstly, a Theoretical Study was carried out to identify some examples of environment friendly building materials used in affordable housing around the world. Secondly, an analytical Study numbers of successful examples of low income housing projects in a number of developing countries and worldwide. At the last section of the research. A simulation program (DB) Design Builder had been used to evaluate the thermal performance of the examined housing unit located in Egypt and examining proposal on improving it by using sustainable building material.

\section{SUSTAINABLE BUILDING MATERIAL}

Sustainable Materials Management ensures the availability of resources for future generations by lessening the amount of the materials we use in our daily life. It leads to a more efficient use of energy, water and materials, reduces the volume and toxicity of waste and can provide economic benefits.

- Environmental benefits (Enhancing Biodiversity-Reducing waste).

- Economic Benefits (minimizing operating costs- enhancing productivity-improving asset value and profits).

- Social Benefits (Enhancing occupant health and comfortImprove indoor air quality- Minimize).

These materials are environmentally important because impacts are considered over the life of the product. Sustainable materials are used throughout consumer and industrial economy that can be produced without consuming resources and without disrupting environmental biological balance and key natural resource systems ${ }^{(1)}$.

\section{MATERIAL SELECTION PROCESS}

There are specific criteria used for the selection of Sustainable building materials such as ${ }^{(2)}$ :

- Thermal efficiency and Recyclability.

- Locally produced and sourced materials.

- Toxic emissions and health consideration.

- Pollution generated in manufacturing process.

- Financial viability, maintenance costs, transport costs and Energy required in the manufacturing process ${ }^{(3)}$.

\begin{tabular}{|c|c|c|}
\hline $\begin{array}{c}\text { Manufacturing } \\
\text { Process }\end{array}$ & $\begin{array}{l}\text { Building } \\
\text { Operation }\end{array}$ & $\begin{array}{c}\text { Waste } \\
\text { Mangment }\end{array}$ \\
\hline $\begin{array}{l}\text { - Waste } \\
\text { Reduction. } \\
\text { - Pollution } \\
\text { Reduction } \\
\text { - Natural } \\
\text { Resources } \\
\text {-Embodied } \\
\text { Energy }\end{array}$ & $\begin{array}{l}\text { •Energy } \\
\text { Efficiency } \\
\text { - Water } \\
\text { Conservation } \\
\text { - Longer Life } \\
\text { - Nontoxic } \\
\text { - Renewable } \\
\text { Energy } \\
\text { Resources }\end{array}$ & $\begin{array}{l}\text { - Recyclable } \\
\text { - Reusable } \\
\text { - Biodegradable }\end{array}$ \\
\hline
\end{tabular}

Fig. 1. Green features of Sustainable Building material ${ }^{3}$

\section{LIFE CYCLE OF SUSTAINABLE BUILDING MATERIAL}

It is a process of identifying the complete life cycle of the product starting from the extraction, and ending with the product disposal. It is also a method for studying its environmental impacts to improve the selection process and to have better alternatives ${ }^{(4)}$.

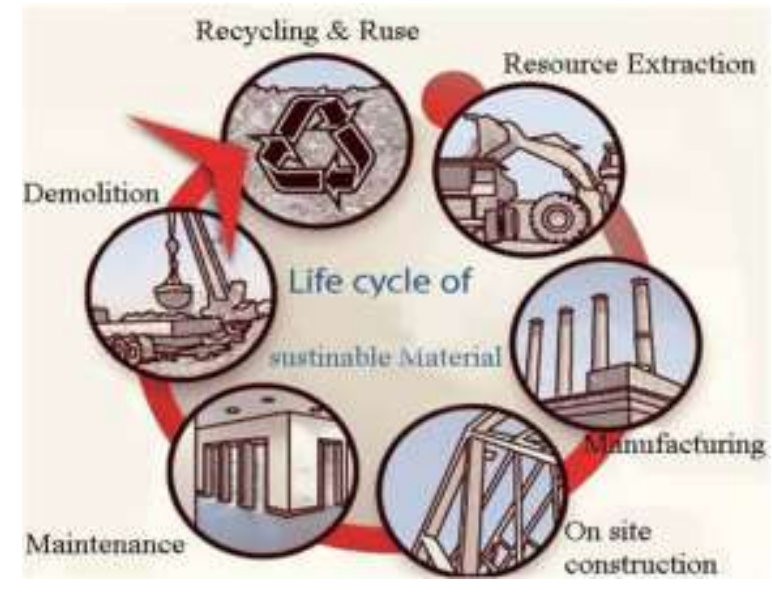

Fig. 2. Life Cycle Design of Sustainable Building Material.

\section{BUILDING MATERIAL OF EgYPTIAN LOW INCOME HOUSING PROJECTS}

According to the definition exists in the last update in 2015 of the (law of mortgage law 148 of year 2001) the low income housing projects are made for households earning 3000 EGP per month ${ }^{(5)}$. The problem is that the price of these unites are not appropriate for low income citizens. Add to that, two-thirds of the Egyptian workforce are not formally employed with 
contracts. This issue can be solved by minimizing the cost through modular construction, prefabrication, and low cost materials ${ }^{(6)}$.

\section{1) Reinforced concrete}

Used for the main structure but it has negative impacts on environment such as: huge amount of energy consumption, consuming of nature aggregates, high embodied energy and $\mathrm{CO} 2$ emissions from cement industry.

2) Clay bricks

It is used for interior and exterior walls of a uniform size (25 $\mathrm{x} 12 \times 6.5 \mathrm{~cm})$. They relatively cheap brick which are dried and burnt at a high temperature and cost 478.5 EGP/ 1000 bricks (Ministry of Housing, 2015).

3) Interior Wall Finishing Materials

The most commonly used materials are emulsion paints. Their prices according to (Ministry of Housing, 2015) range from 8.6 to $37 \mathrm{EGP} / \mathrm{L}$. Cement plaster is applied to the interior walls to give smoothness then Primer is applied as a to protect the layer being painted.

4) Floor Finishing Materials

Ceramic tiles of size $31.5 \times 31.5 \mathrm{~cm}$ with price of $41 \mathrm{LE} / \mathrm{m}^{2}$ are used (Ministry of Housing, 2015). They are used since they are affordable and considered more resistant compared to other surfaces.

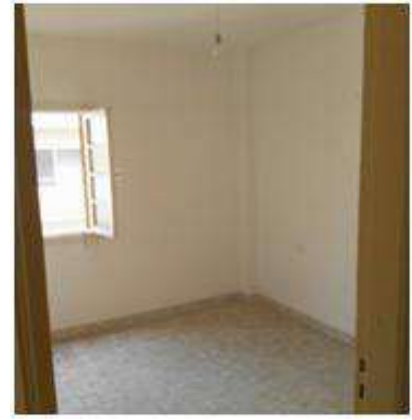

(a)

fig. 3. A view from inside low income housing unit in Egypt in Gharbiya governorate (a) Master bed room (b) living room.

TABLE I

CONVENTIONAL BUILDING MATERIAL HARMFUL EFFECTS.

\begin{tabular}{l||l}
\multicolumn{1}{c|}{ Material } & \multicolumn{1}{c}{ Harmful Effect } \\
\hline $\begin{array}{l}\text { Smoke and harmful } \\
\text { gases emission }\end{array}$ & $\begin{array}{l}\text { Redbrick industry causes emission of huge } \\
\text { quantity of toxic elements from brick kilns } \\
\text { is causing serious health hazards. }\end{array}$ \\
\hline $\begin{array}{l}\text { Modern acrylic } \\
\text { paints }\end{array}$ & $\begin{array}{l}\text { Trap moisture in the wall and impede the } \\
\text { movement of the heat }\end{array}$ \\
\hline Asbestos & $\begin{array}{l}\text { In sheeting products, or thermal insulation to } \\
\text { heating systems), causes lung cancer. }\end{array}$ \\
\hline $\begin{array}{l}\text { Volatile Organic } \\
\text { compounds }\end{array}$ & $\begin{array}{l}\text { It's better to use water-based eco-paints and } \\
\text { varnishes without ammonia. }\end{array}$
\end{tabular}

\section{EFFECT OF BUILDING MATERIAL ON HUMAN THERMAL COMFORT}

Due to difference in air temperature between outside and inside, a specific amount of heat flows through a building's skin. The type of external building's skin material represents the
Main Factor in achieving suitable indoor thermal environment. There are two physical Properties thermal resistance R-value and Thermal Conductance (U-value).

\section{SUSTAINABLE MATERIAL}

\section{A. Rice - Straw Brick:}

In Egypt, Rice straw residuals are around 3.5 million tons per year. Burning it causes air pollution and health problems. The ministry of environmental affairs started establishing factories for making use of rice straw ashes by converting it to useful products such as untraditional fertilizers and bio fuels to reduce air pollution. A number of Egyptian studies and researches have been made to discuss the possibility of using it in brick industry as low-cost housing sustainable materials. It can be recycled by mixing it with cement to develop a new composite straw-cement blocks which is cheap, recyclable and high thermal insulation units, the materials for straw-cement wall would cost about $\$ 2.5$ per $1 \mathrm{~m}^{2}$ but the unit cost of the red brick wall is about $\$ 20$ per meter square ${ }^{(7)}$.

TABLEII

RICE STRAW BRICK PHYSICAL PROPERTIES

\begin{tabular}{|l|l|}
\hline \multicolumn{2}{|l|}{ Physical properties } \\
\hline Dimensions $(\mathrm{cm})$ & $25 \times 12 \times 13$ \\
\hline K-value & 0.41 \\
\hline Density $\left(\mathrm{Kg} / \mathrm{m}^{3}\right)$ & 1545 \\
\hline Stress $\left(\mathrm{Kg} / \mathrm{cm}^{2}\right)$ & 18.7 \\
\hline
\end{tabular}

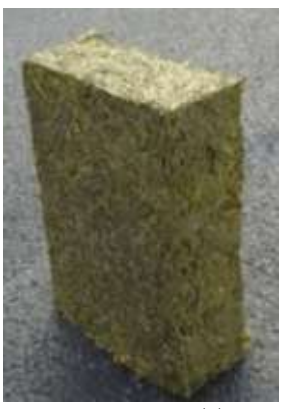

(a)

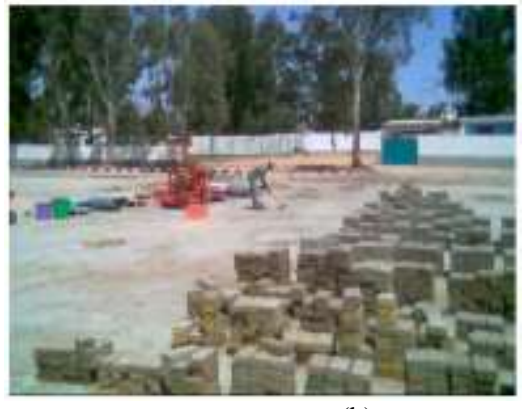

(b) fig. 4. (a) Final straw-cement block (b) solid rice-straw based brick.

\section{B. Compressed Earth Blocks (CEB):}

They are made by using a device to compress the earth inside a mold. The Egyptian Earth Construction Association concluded that CEB is a good material for walls it can be appropriate alternative material in Egypt. The1000 blocks cost 450 EGP, which is equal to the price of the fired clay bricks produced at the fully mechanized factories. Their manufacture consumes less energy. The Egyptian Building National Research Center is currently writing a code for stabilized earth construction $^{(8)}$. 


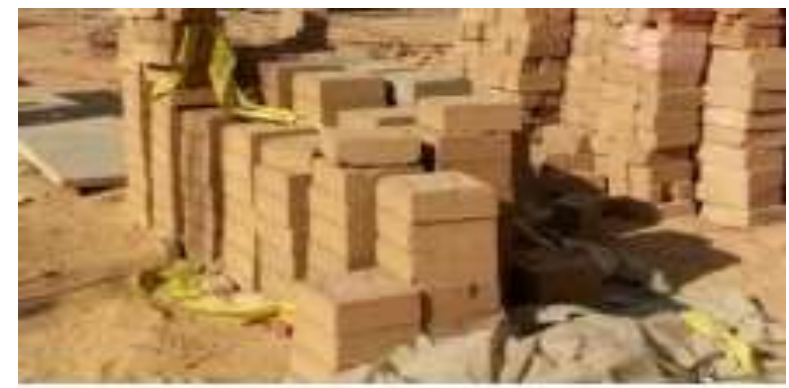

Fig. 5. CSEB Blocks Produced at the Housing and Building Research Center Headquarters

\section{HBRC New Bricks}

The Egyptian Housing and Building National Research Center (HBRC) has created new bricks from Industrial, agricultural solid wastes. It was an innovative idea to convert solid wastes into building material as Egypt generates 75 million tons of solid waste annually. Theses bricks made from different type of Wastes ${ }^{(9)}$

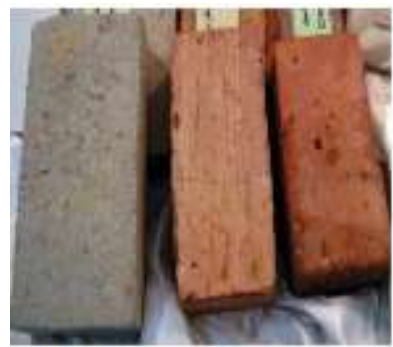

(a)

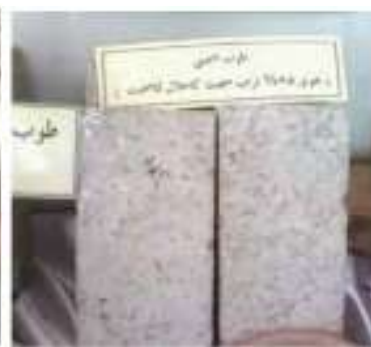

(b)
Fig. 6. HBRC New Bricks (a) Cement dust brick (b) recycled clay brick.

\section{Innovida Wall Panels}

They are thick wall panels fabricated from two sheets of (glass-fiber composite encapsulating an expanded polyurethane core). Construction cost does not exceed $40 \%$ of the traditional cost. It can build $35 \mathrm{~m} 2$ in one day. Its thermal properties can be changed to suite each site climate condition by using different kinds of fiberglass fabric. The Panels can be modified by using higher R-value if required. As a result, many Countries started using this technique such as Turkey, Egypt, Oman and United Arab Emirates ${ }^{(10)}$.

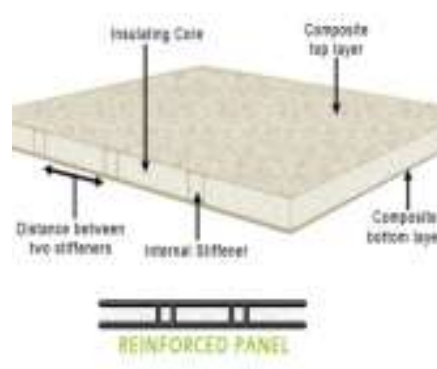

(a)

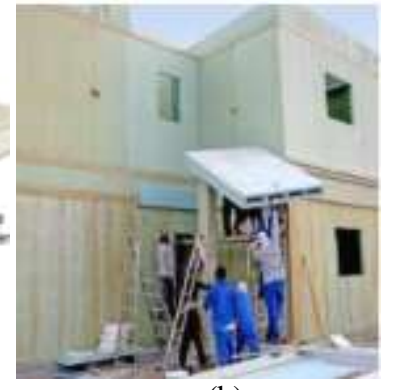

(b)
Fig. 7. (a) Component of Innovida Wall (b) Construction process.

\section{E. Aerocon Panels}

Aerocon panels are inorganic sandwich panels made of two fiber reinforced cement sheets with a light-weight core consisting of Portland cement and binders. The use of Fly ash and its substitution for timber based products makes this panel environmental-friendly. ${ }^{(11)}$

\section{F. Advantages of using Aerocon Panels:}

- They are eco-friendly, thin walls (space saving), light weight.

- Thermal conductivity of a $50 \mathrm{~mm}$ Aerocon board is $0.22 \mathrm{~W} / \mathrm{m}$. k, its weight is $39 \mathrm{~kg}$.

- Faster construction, no wet plastering, high thermal insulation, excellent sound reduction, suitable for Seismic.

- Fire, Water, termite and resistant panels.

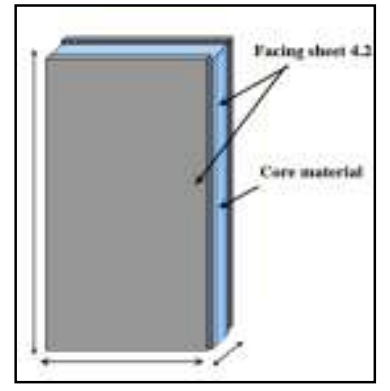

(a)

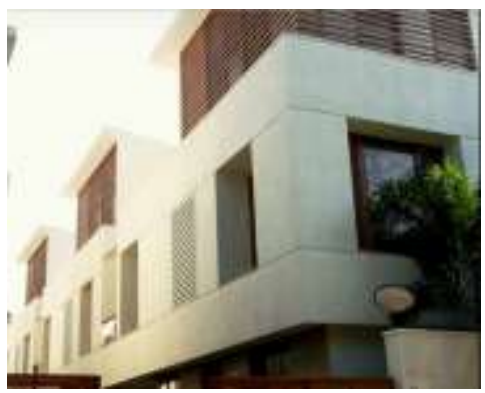

(b)
Fig. 7. (a) Aerocon Panels component (b) housing project with Aerocon Panels

\section{G. Vinyl and Fiberglass frame (double glazed) window:}

In hot climates, they show better performance in compare to aluminum and wooden windows. Vinyl windows are low costing, high performance and durable. They have good insulating properties, low maintenance. Also they come in a variety of colors and finishes. Vinyl and fiberglass window frame are the most energy efficient. Aluminum windows are not suitable residential buildings due to high heat loss/gain in form of conduction while wooden windows could be used after covering its exterior with aluminum to protect it from rain, moisture and UV sun rays ${ }^{(12) .}$

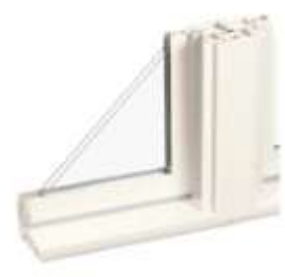

(a)

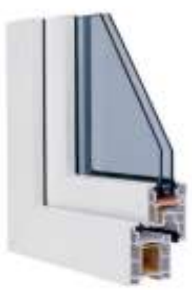

(b)

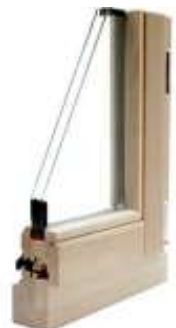

(c)
Fig. 8. Sustainable window frame (a) Fiber glass (b) Vinyl (c) Wood

\section{H. Cork Flooring}

Rapidly renewable material with superior durability characteristics, cork density is extremely low giving the material high insulating properties. It does not absorb dust meaning it will not hold harmful indoor air pollutants such as 
VOCs (Volatile organic compounds). Finally, cork is a natural fire retardant and does not spread flames or release toxic gases when burnt. Its installation products are all water-based and solvent-free with low VOC emission ${ }^{(1)}$.

\section{Bamboo floor}

Bamboo can be both used in exterior and interior design elements. It is a sustainable and sturdy building material

\section{J. Linoleum}

It is considered a Natural, renewable, durable and lowmaintenance material, creating energy at the end of its useful life.

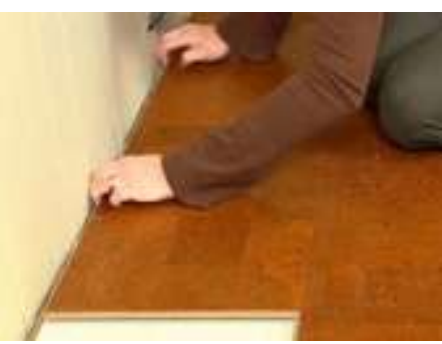

(a)

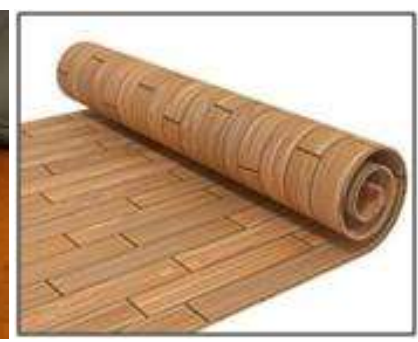

(b)
Fig. 9. Sustainable floor tiles (a)Crock tiles (b) Linoleum

\section{K. Insulation Material}

A lot of Agricultural waste can be used as sustainable thermal insulation products which are (Bagasse, Rice hulls and Coconut coir). They all have has low thermal conductivity, and low embodied energy and environmental friendly material Add to that Rice Hulls insulation boards have lower moisture content and higher fire protection. A rating has been developed to identify the environmental thermal insulating materials from the ecological point of view. Each material has a score of the sum of the following indicates (insulation value, toxicity, waste disposal, diffusivity, cost, fire resistance) to help the architect, engineer or builder to select the appropriate ecological Insulation Material $^{(13)}$.

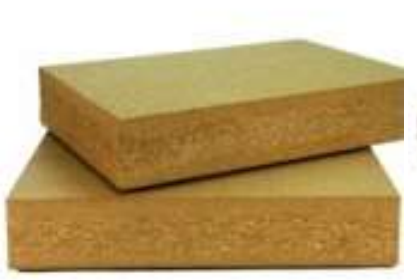

(a)

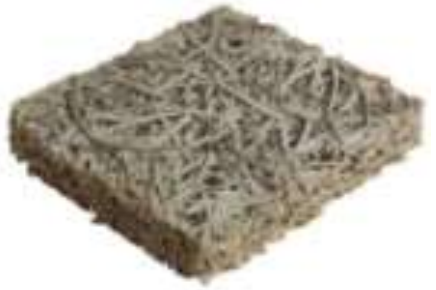

(b)
Fig. 10. Sustainable insulation material (a) Straw board (b) wood wool board.

\section{INTERNATIONAL LOW INCOME E HOUSING PROJECTS}

\section{A. Sandbag Affordable Houses}

This housing project located in South Africa and was built in 2009 by a total cost of 6.000 dollar by using sustainable effective building material. Inexpensive local Sandbag was used as a building material where it conserves money and resources. It was constructed with the help of its future. The project was built using the Eco Beams system which was used to frame the house. The vertical beams are made of timber connected with a galvanized metal element. Each housing unit consists of two stories, two bedrooms and a balcony upstairs with space out back for gardening. It is nothing luxurious; just $53.9 \mathrm{~m}^{2}$. It has more room and character than the homes of the South Africa's government. ${ }^{(14)}$

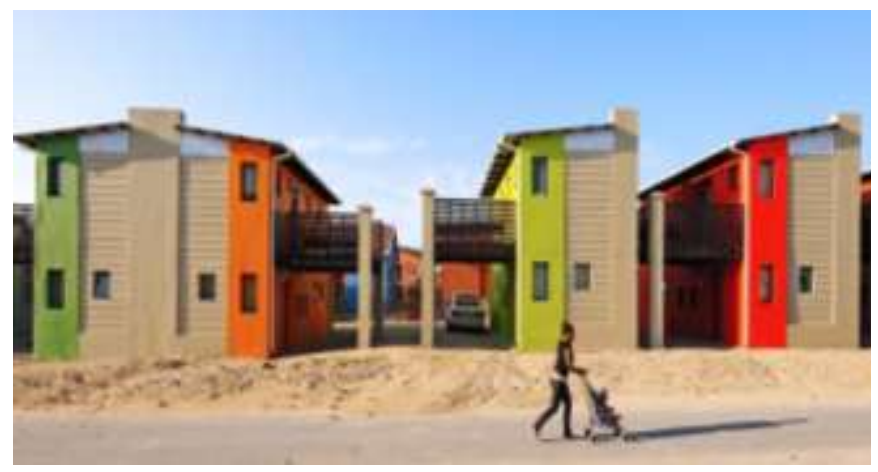

Fig. 11. Side view of sand bag housing project

\section{1) Sustainable Building Material}

This building technique is a strong, safe, easily available, easily transferable and cheap way of providing affordable housing. When it comes to maintenance, during the life span of the building, the material is available on site. It allows communities to build their own homes. The houses are earthquake safe, fire proof, wind proof, sound proof, and water proof, economical and the system is in addition, sandbags can be up to 40-percent cheaper than brick. It has extremely good thermal properties. When sandbag houses are completed with plastered exterior and interior walls, they will look identical to a house built from conventional materials.
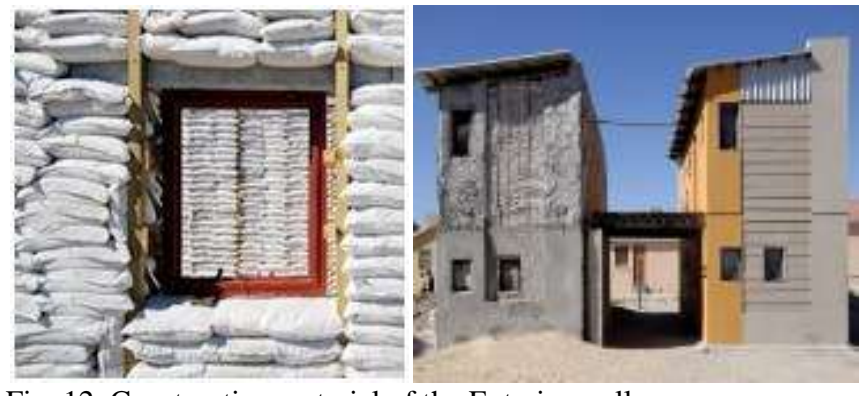

Fig. 12. Construction material of the Exterior wall

\section{B. Wozoco Apartments}

Low income housing project with 7,500 $\mathrm{m} 2$ was built in Amsterdam in 1997 by using local wood as Sustainable Construction material and technique. It offers a variety of materials including: wood siding, colored glass balconies, metal railings, reinforced cement panels, and pattern of different sized windows and balconies. Because most of the budget was spent for the structural aspects of the cantilevered units, the building uses cheap, local wood siding and a curtain wall system for the north façade ${ }^{(15)}$ 


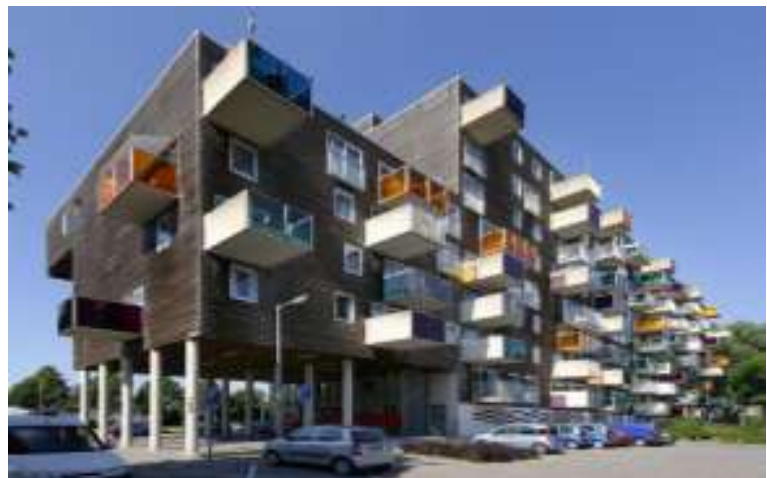

Fig. 13. Low income housing project Wozoco

\section{CASE STUdY BACKGROUND: EgYPTIAN NATIONAL HOUSING UNIT}

This project was built in 2005 and completed in 2011 with total Budget of 34 billion dollars by Housing ministry. This project was built to solve housing problem for youth and low income sector with an average of 85,000 units per year and a total of 500,000 units in 6 years ${ }^{(16)}$.

TABLE III

EGYPTIAN NATIONAL HOUSING PROJECT INFORMATION

\begin{tabular}{l||l} 
Unites area & $90 \mathrm{~m}^{2}$ \\
\hline Project Date & $\begin{array}{l}\text { Started in 2005 } \\
\text { completed in 2011 }\end{array}$ \\
\hline Propose & $\begin{array}{l}\text { Providing housing units for youth and low } \\
\text { income sector with an average of 85,000 } \\
\text { units per year and a total of 500,000 units } \\
\text { in 6 years. }\end{array}$ \\
\hline Cost & $\begin{array}{l}\text { Budget }=238 \text { billion LE } \\
\text { Unit cost }=50.000 \text { LE }\end{array}$ \\
\hline Description & (Ground floor +5 stories). Each floor \\
& consists of 4 apartments.
\end{tabular}

Each one has (3bed rooms- Living roomKitchen-bathroom).

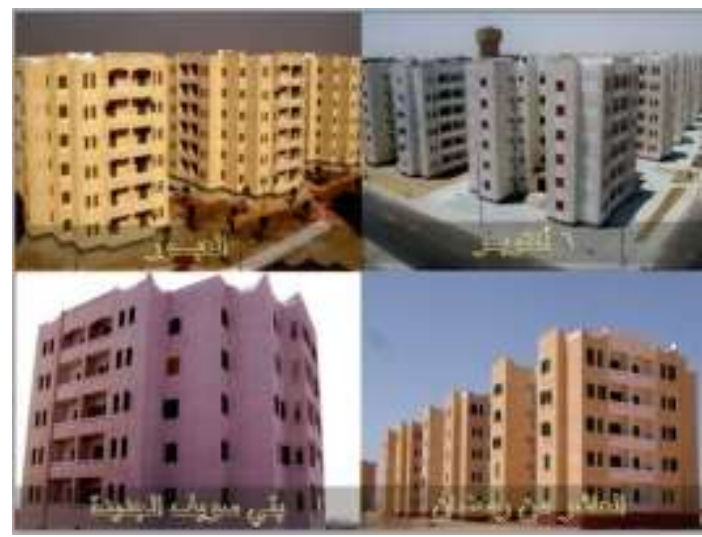

Fig. 14. The housing units design in different governorates

\section{A. Building material}

This selection process has massive effect on housing projects cost in Egypt where the cost of materials takes up to 70 percent of low-income housing unit. Despite having a number of natural resources of raw building material that can be used in sustainable constructions of housing project, we depend mainly on imported building materials and technologies ${ }^{(17)}$.

\section{B. Simulation Tool: Design builder software}

It is a user-friendly modeling software tool for creating and checking building energy and environmental analysis, lighting and comfort performance. It is a comprehensive interface for Energy Plus. Add to that It provides advanced modeling tools in an easy-to-use interface, compare the function and performance of the building and deliver results on time and budget. The advantages of using Design Builder as a simulation program $^{(18)}$ :

- It offers flexible geometry input, extensive material libraries and load profiles.

- Displaying and analyzing Simulation results in a comprehensive manner.

- The ability of controlling procedures which assure the accuracy of the results.

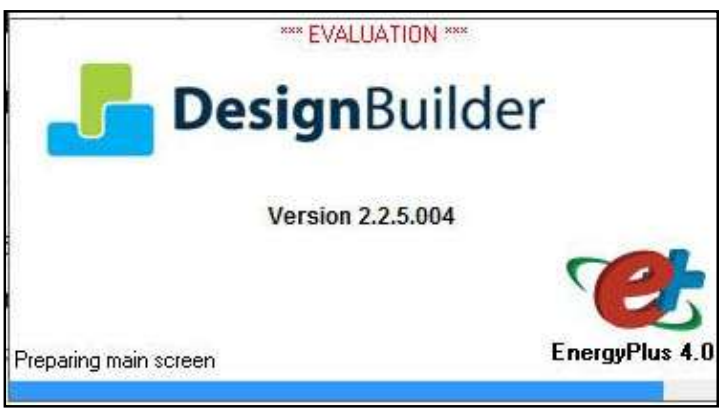

Fig. 15. Design Builder software interface

\section{EVALUATION OF THE CURRENT DESIGN}

A. Simulation results for the current design

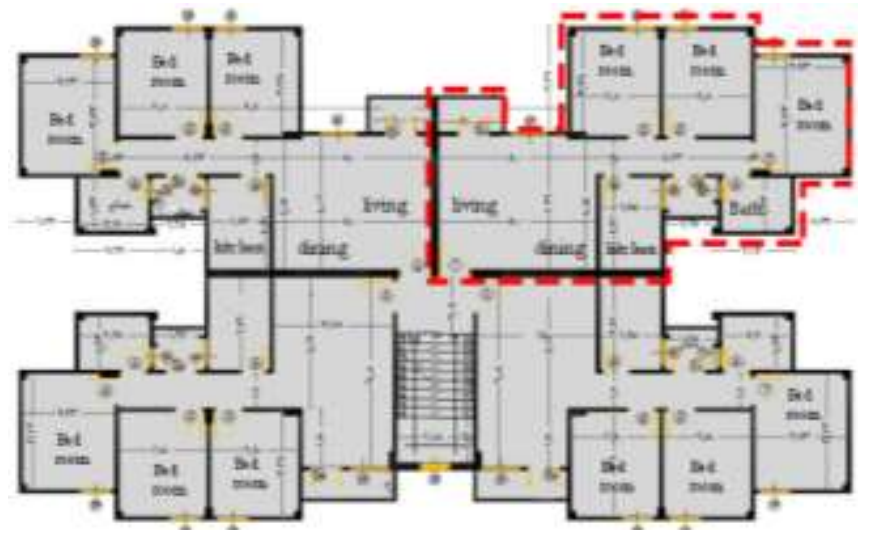

Fig. 16. Master plan of the 6 th floor of the National Housing project 


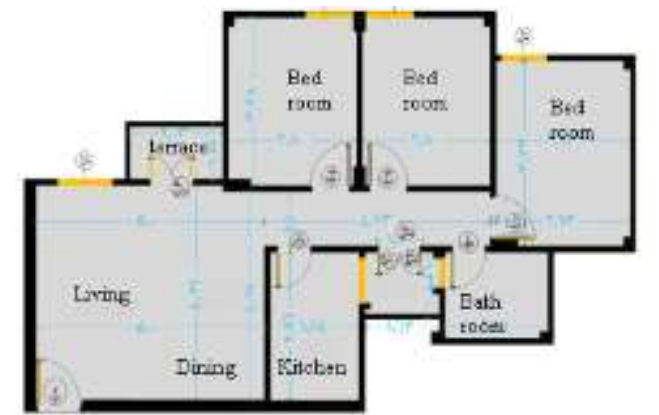

Fig. 17. Floor plan of examined (North East) apartment in 6 th floor

The simulation process take place in was the north east apartment (master bed room) zone 13 in the 6 floor which is the last floor and it represent the worst case, the simulation process occurred for all months of the year for the whole day hours. The simulation period was chosen for summer typical week.

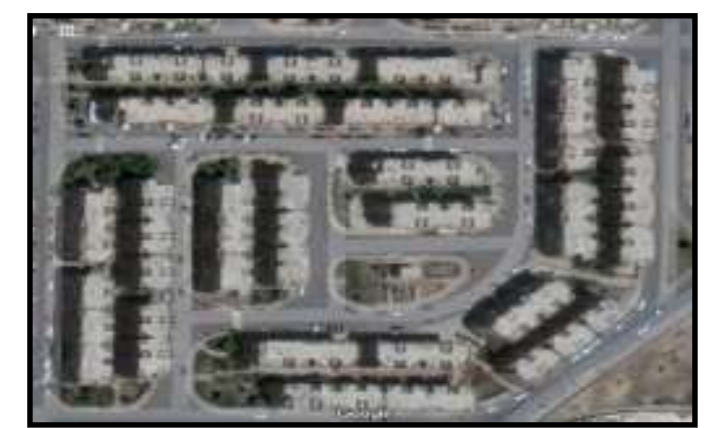

Fig. 18. Layout of the national housing project cluster in new Cairo.

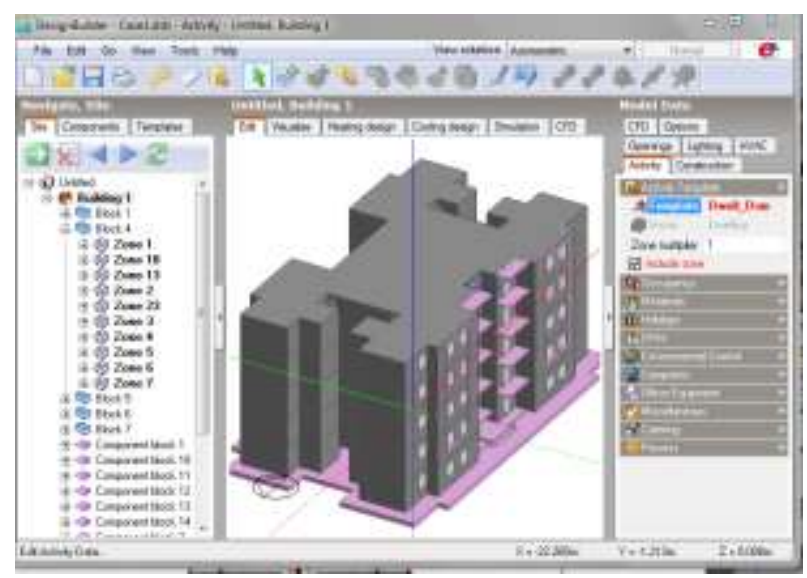

Fig. 20. Building the $3 \mathrm{~d}$ model in design builder Edit tab

Simulation Process Steps:

1. Draw building blocks to create building geometry and different levels.

2. Selecting the weather data file of the selected site

3. Add custom openings (windows, doors).

4. Setting Building material of walls windows, doors, floor of the model.

5. Set Activity Data for the Building and for each zone in the residential building.

6. Running simulations to how thermal comfort results on the selected zone

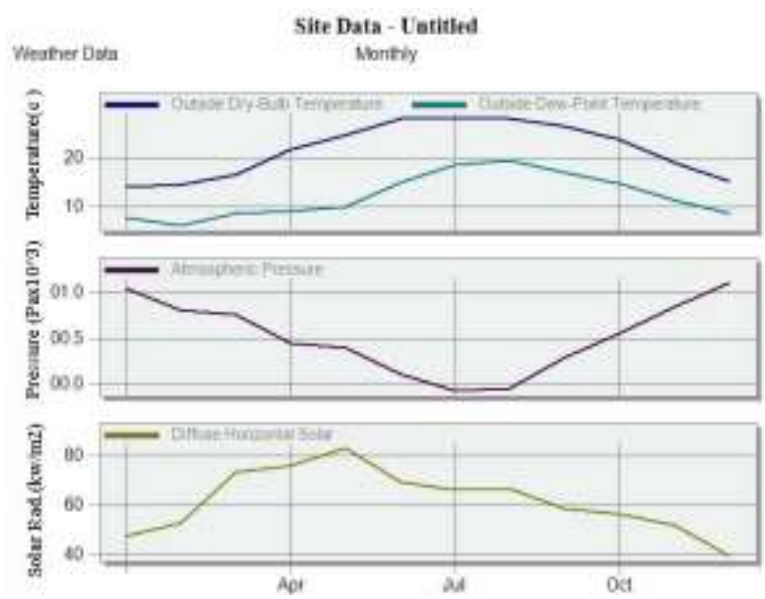

Fig. 21. Project Site Monthly Weather Data

The previous figure shows the site weather data of new Cairo (outside dry-bulb temperature, outside dew-point temperature, atmospheric pressure and diffuse horizontal solar energy) the maximum outside dry-bulb temperature of 28.18 $\mathrm{c}^{\circ}$ in the month of July and a minimum of $13.51 \mathrm{c}^{\circ}$ in January. Maximum outside dew-point temperature is $19.39 \mathrm{c}^{\circ}$ in the month of august and the minimum being $6.26 \mathrm{c}^{\circ}$ in February.

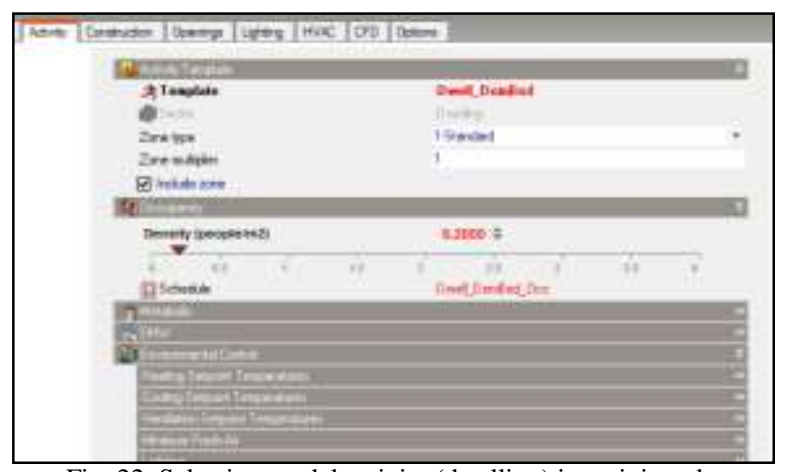

Fig. 22. Selecting model activity (dwelling) in activity tab

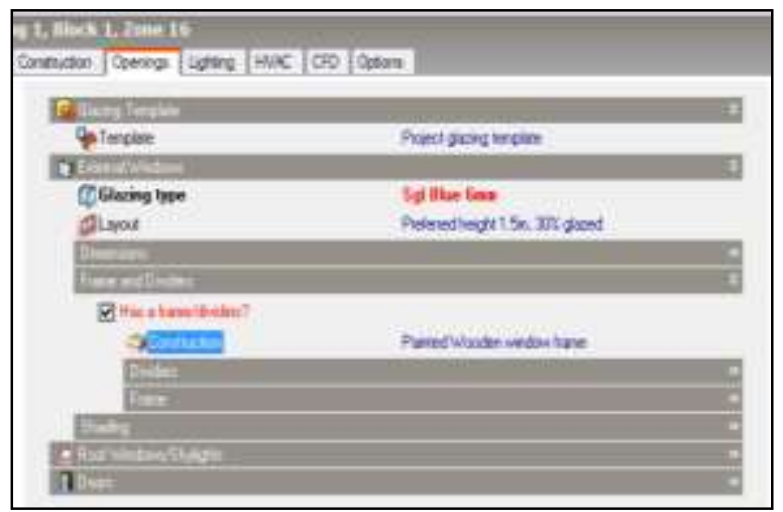

Fig. 23. Adding model opening data in opening tab 


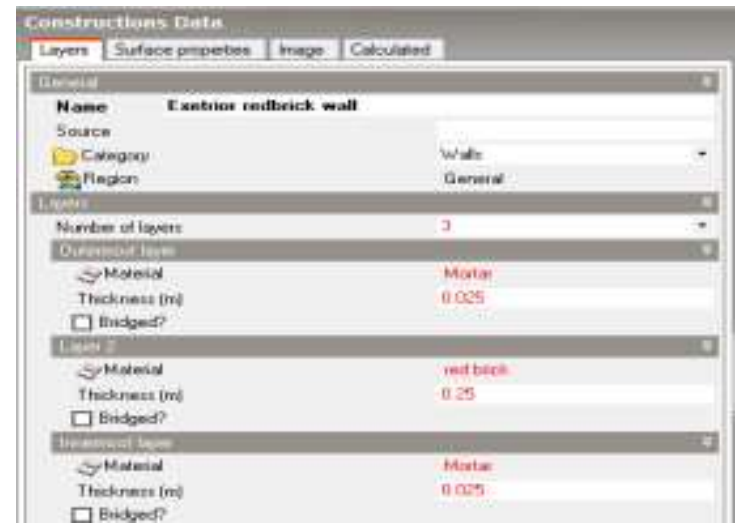

Fig. 24. Adding model construction material of the building tab

The previous figure shows the site data of the project selected location (Cairo) which indicate the outside dry temperature, the pressure and the solar radiation during months of the year which is detected after entering the weather data file in the simulation software.

\section{B. Simulation Results of the Current Indoor Design}

\section{1) Thermal Comfort Analysis:}

The following figure shows the internal air temperature, operative temperature (comfort temperature) and the outside Dry-Bulb air temperature of the studied zone (master bed room) in the north during the year.

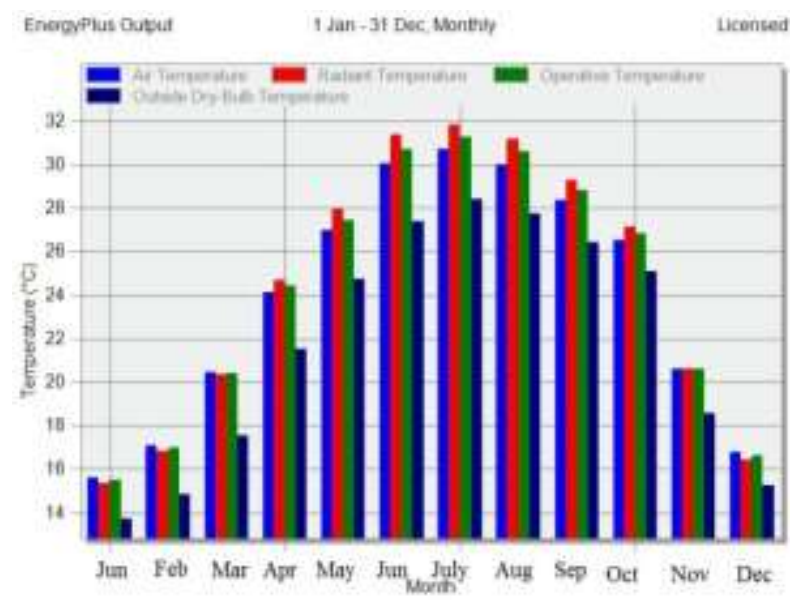

Fig. 25. Temperature and Heat Gain of the Residential Unit.

- The Maximum air temperature was $31.2 \mathrm{c}^{\circ}$ in July and its minimum is $19.1 \mathrm{c}^{\circ}$ in July.

- The Maximum Radiant temperature is $31.98 c^{\circ}$ in July and the minimum is $19.2 \mathrm{c}^{\circ}$ in January.

-The Maximum Operative temperature is $31.36 c^{\circ}$ in July and the minimum is $19.3 \mathrm{c}^{\circ}$ in January.

- Maximum relative humidity is 50\% in July and the minimum is $36 \%$ in May.

By examining the performance of the current building material of the (walls, opening, floor) of the residential model. It was detected that the internal air temperature is above the human comfort temperature in the hottest month of the year which negatively affect the human thermal comfort and leads to excessive using of mechanical ventilation system and increasing energy demand.

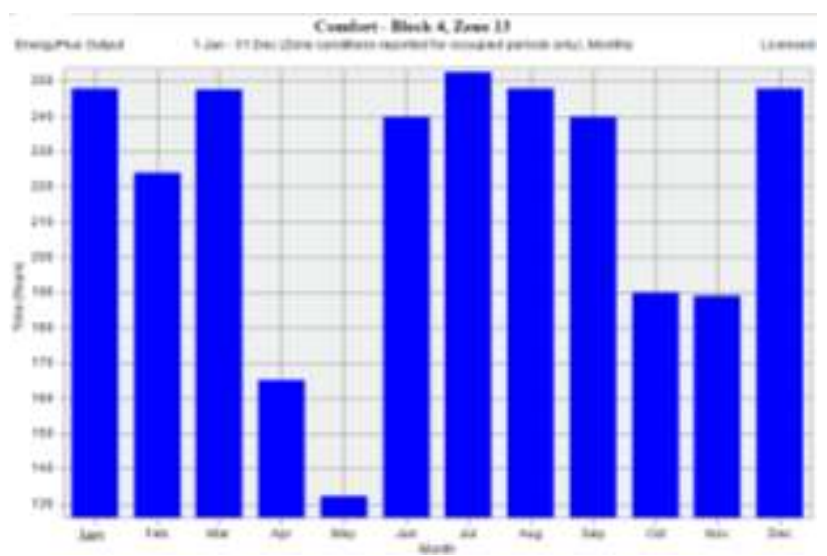

Fig. 26. Discomfort hours of the selected zone 13 (Northern Bed room) over the year.

On monthly comparison, the month of July had the highest number of discomfort hours of 260 hours and the lowest discomfort hours were in the month of May at 135 hours. This result could be attributed to the high relative humidity recorded in the month of May and lowest relative humidity in February. Maximum relative humidity is $50 \%$ in July and the lowest is $36 \%$ in May. It is generally observed that maximum temperatures are in the month of July.

\section{Simulation Results after modifications}

The following Simulation results after replacing the current building by sustainable alternatives:

TABLE IV

PROPOSED MODIFICATION OF WALL CONSTRUCTION MATERIAL

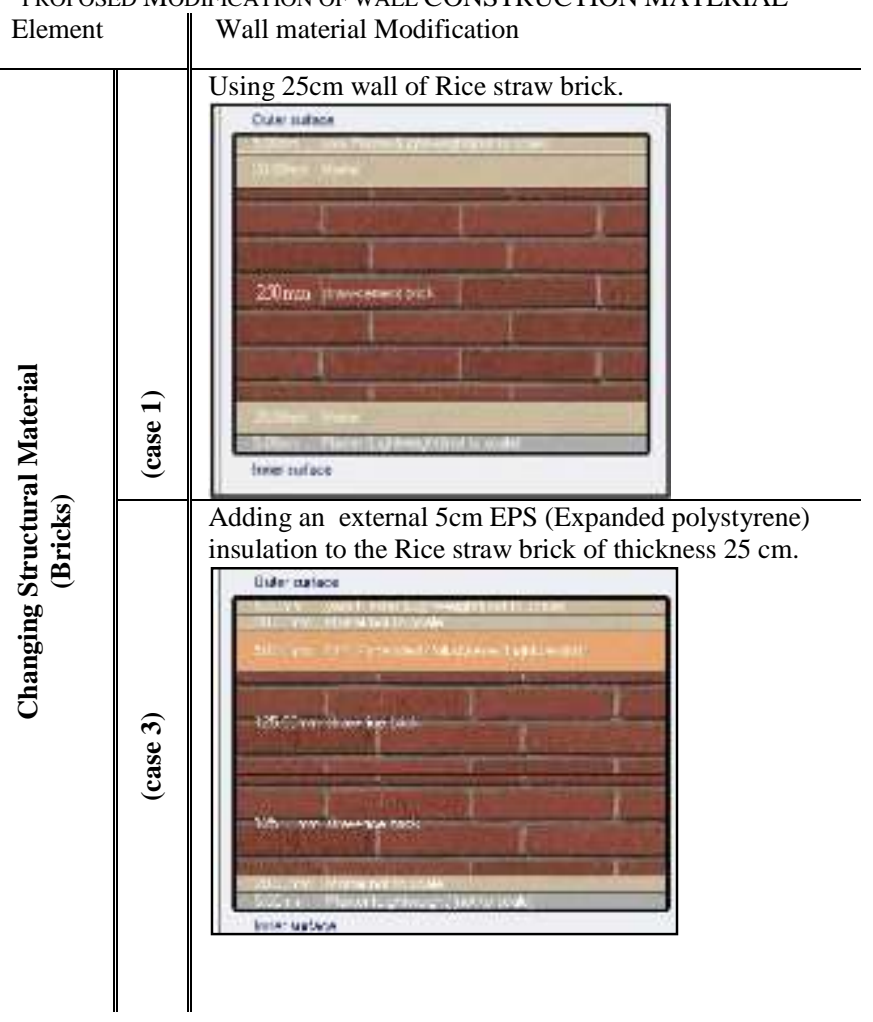


TABLE V

PROPOSED MODIFICATION OF FLOOR AND OPENING MATERIALS

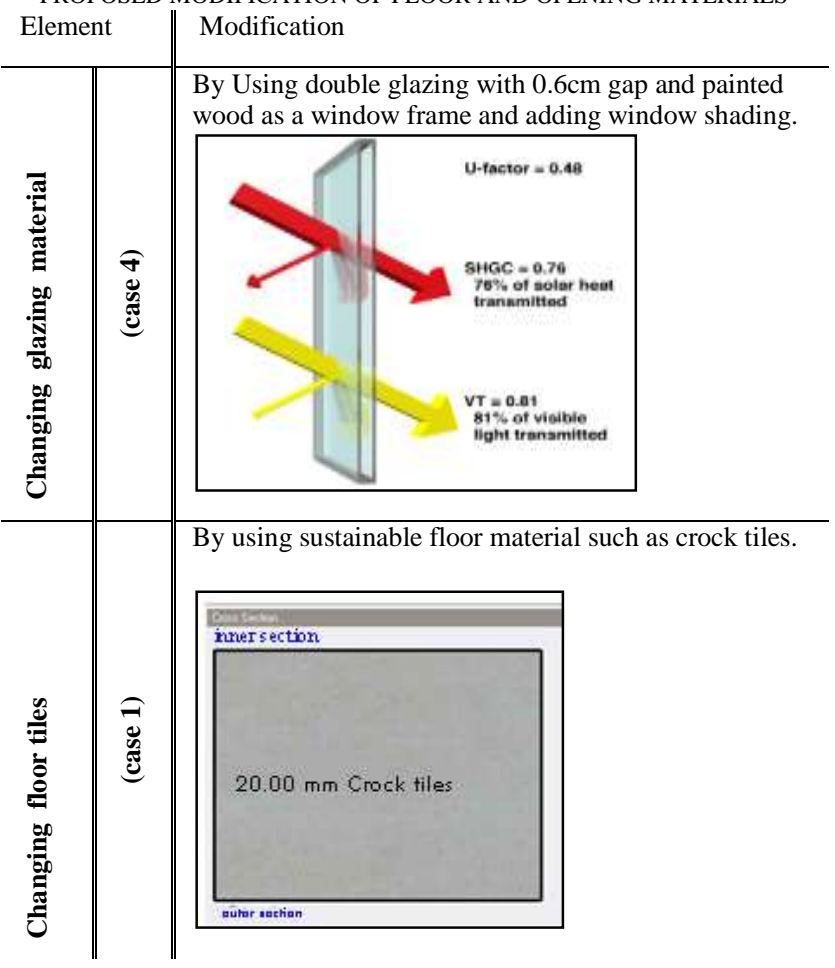

\section{1) First Case:}

The simulation results shows that by replacing red brick of the exterior and interior walls by rice straw brick a reduction in internal air temperature occurred by $2 \mathrm{c}^{\circ}$ during the whole day.

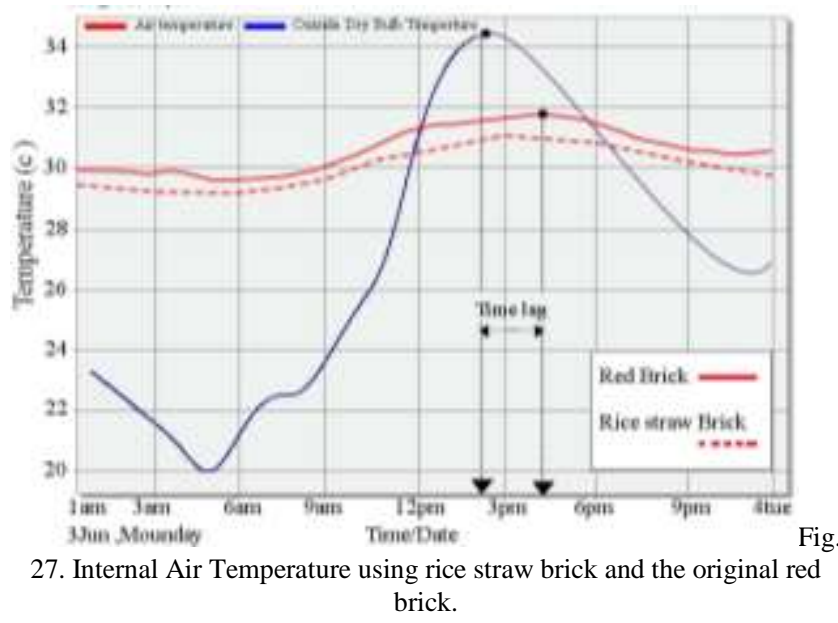

2) Second Case:

The simulation results show that by showed the most reduction in internal air temperature of the tested (zone 13). these reduction was caused by increasing the thickness the wall into $25 \mathrm{~cm}$ and adding an external layer of insulation material. As shown in figure (22), the lowest air temperature was $26.9 \mathrm{c}^{\circ}$ and the highest was $30.2 \mathrm{c}^{\circ}$.

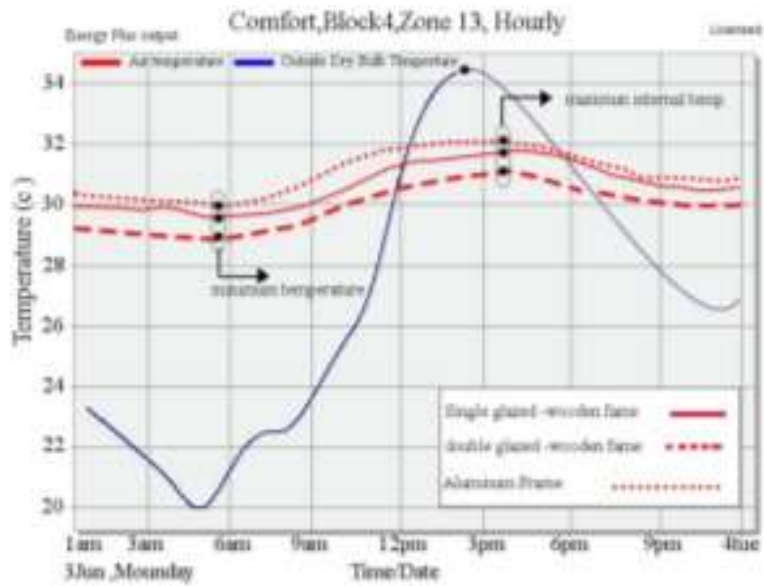

Fig. 28. Internal air temperature with different opening (windows) material

\section{3) Fourth Case}

This case examines in the impact of changing windows frame and glazing material on of the studied model on the internal air temperature by using alternative sustainable material instead of the original material. In figure (23) by using double glazed of window of $0.6 \mathrm{~cm}$ air gap and a sustainable wooden frame, the internal air temperature drops by approximately $1 \mathrm{c}^{\circ}$ compared with the original case (single glazed window) Throughout the day and night time where the highest degree records $32.5 \mathrm{c}^{\circ}$ at 3 am and the lowest is $29^{\circ}$ at $5 \mathrm{am}$.while aluminum famed window represent the worst material for opening.

4) Fifth Case:

This part examines in the impact of changing floor finishing

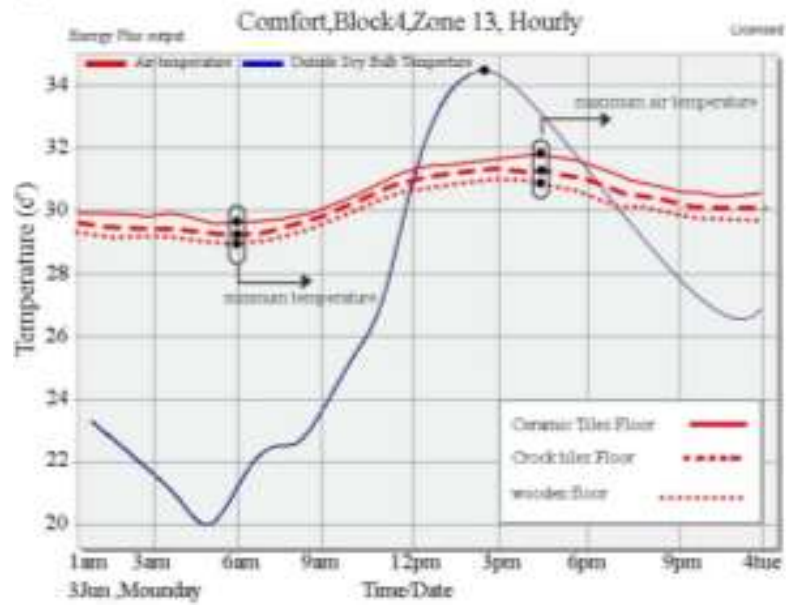

Fig. 29. Internal air Temperature with Different Floor Material.

material of the studied model on the internal air temperature by using alternative sustainable material instead of the original material. the used floor material is (crock - soft wood). Figure (27) shows the internal air temperature of zone 13(master bed room) in the north of the residential model. the simulation process take place in the floor.

It is observed that using crock tiles decreases the internal air temperature by $1.5 \mathrm{c}^{\circ}$ compared by ceramic tiles where the internal air temperature while using ceramic tiles reaches its peak $340 \mathrm{c}$ at 4 am the lowest was $29 \mathrm{c}^{\circ}$ at $5 \mathrm{am}$ 
and $12 \mathrm{pm}$. On the other hand, crock tiles records its heights degree where $38 \mathrm{c}^{\circ}$ at5 $3 \mathrm{am}$ and its lowest degree was $28 \mathrm{c}^{\circ}$ at $5 \mathrm{am}$.

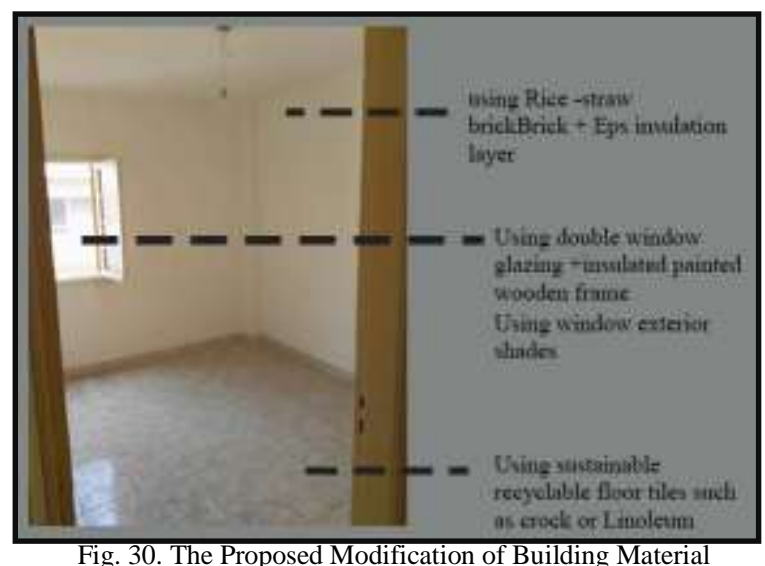

XIII. CONCLUSION

The study focuses on the effect of building material selection in low income housing project on the thermal performance of these residential units, the internal air temperature, the overall cost and thermal comfort of occupant. This information can be used to estimate the material sustainable alternatives which can be used to change futuristic design of this type of projects, and to identify the major design problems for energy efficiency. This investigation has been done for a suggested prototype unite in new Cairo.

\section{RECOMMENDATIONS}

To make the best choice of appropriate building material for Egyptian low income housing projects the researcher recommended that some aspects should be regarded:

1) Choosing recyclable environmental material from local environment due to its capabilities of enhancing human thermal comfort.

2) Using alternative materials will affect the total building cost which will make these governmental housing projects more affordable for youth and low income citizens.

Proposed Sustainable Alternative Building Material:

\section{A. For Walls:}

Straw- rice brick can be a sustainable replacement for red brick and can also due to its low thermal transmittance it can improve indoor internal temperature thermal. Also increasing the wall thickness from $12.5 \mathrm{~cm}$ to $25 \mathrm{~cm}$ will affect the internal air temperature

\section{B. For Floor:}

Crock tiles can be an environmental material for floor material and an affordable choice. It increases the sensation of thermal comfort. Soft wood also can be a good replacement but it is expensive and can be replaced by bamboo sheets. C. For openings:

\section{1) Windows:}

Double glazed windows with $0.6 \mathrm{~cm}$ gap and painted wooden frame as an external opening material is more efficient than single glazing. but the current aluminum window frames are bad choice for housing unit in Egypt climate.

2) Doors:

Using MDF (medium density fiber board) doors is more suitable where they are harder and durable though not as strong as solid wood but cheaper. Insulated wood panel or fiberglass doors are very efficient door material but they are expensive.

\section{REFERENCES}

[1] S. Sharma, (2015, Jul16.). Sustainable Materials for Building Construction. [Online]. Available: https://www.scribd.com/ sustainable construction material.

[2] L.Thompson, "Sustinable materials," The Struggle for Integrated Sustainable Settlements, 1st ed., vol.1, Republic of South Africa.

[3] J. Kim, and B.Rigdon, "Qualities, Use, and Examples of Sustainable Building Materials," . National Pollution Prevention Center. University of Michigan,1998, pp.23-25.

[4] K. Grace, Life Cycle Assessment of sustainable building materials. University of Technology Sydney. Australia.

[5] Modification of Evacuative Regulations law of mortgage law 148 of year 2001. Financial regulatory authority. [Online]. Available: http://www.fra.gov.eg. Accessed 17/1/2018.

[6] A. Mustafa, "Optimum Design Of Affordable Housing" M.Sc.Thesis, Dept. Arch.Eng., American University in Cairo., Egypt., 2015.

[7] T. Akmal, and M. Fahmy, (2011), Rice-Straw Based Cement Brick Microclimatic Thermal Impact Assessment in Cairo, World Renewable energy congress, Sweden.

[8] M. Farouk, (2013). Alternative Building Materials for Affordable Housing in Egypt. Ain Shams University. Egypt.

[9] A. Farouk, (2011). An Ecological Residential Buildings Management. Arab Academy for Science. Alexandria University.

[10] B. Ahmed, (2015), clever solutions in buildings and its impact on architecture design.

[11] A.Vidya,and A. Radha, (2015). Alternative Low-Cost Building Materials. Bangalore, India.

[12] R. Divsalar, "Building Problems in Hot Climates," M.S. thesis, Dept. Arch.Eng., Eastern Mediterranean University., North Cyprus.2010.

[13] S.Sharma. (2015, Jul16,). Sustainable materials for building construction. Available[Online]: https://www.scribd.com/doc/271783434/sustainable construction-material.

[14] Housing and building research center library, (2001), thermal insulation work section. Cairo.p. p18-19.

[15] Housing and building research center library, (2001), thermal insulation work section. Cairo.p. p18-19. Accessed 30, September 2017.

[16] T. Barrie, (2017). Affordable Housing Sustainable Communities. Retrieved January 5, 2018 from. [Online].Available: https://design.ncsu.edu.

[17] Executive system of the National Project for Social Housing. (2011). Ministry of Housing and Urban Communities. Egypt.

[18] A. AFIFY, (2005). Improvement of Low-Cost Housing Conditions. El Mataria. Helwan University.

[19] D. Ibarra, (2009). Building Performance Simulation for Designers. Harvard University, United States.

[20] K. Koigi, 2015. Sandbag Project. Available at. [Online]. Available: http://www.archidatum.com/. Accessed 30, September 2017] 